University of Nebraska - Lincoln

DigitalCommons@University of Nebraska - Lincoln

\title{
Nitrogen Contribution of Peanut Residue to Cotton in a Conservation Tillage System
}

\author{
B. Meso \\ Auburn University \\ K. S. Balkcom \\ USDA-ARS, kip.balkcom@ars.usda.gov \\ C. W. Wood \\ Auburn University \\ J. F. Adams \\ Auburn University
}

Follow this and additional works at: https://digitalcommons.unl.edu/usdaarsfacpub

Part of the Agricultural Science Commons

\footnotetext{
Meso, B.; Balkcom, K. S.; Wood, C. W.; and Adams, J. F., "Nitrogen Contribution of Peanut Residue to Cotton in a Conservation Tillage System" (2007). Publications from USDA-ARS / UNL Faculty. 516. https://digitalcommons.unl.edu/usdaarsfacpub/516
}

This Article is brought to you for free and open access by the U.S. Department of Agriculture: Agricultural Research Service, Lincoln, Nebraska at DigitalCommons@University of Nebraska - Lincoln. It has been accepted for inclusion in Publications from USDA-ARS / UNL Faculty by an authorized administrator of DigitalCommons@University of Nebraska - Lincoln. 


\title{
Nitrogen Contribution of Peanut Residue to Cotton in a Conservation Tillage System
}

\author{
B. Meso, ${ }^{1,2}$ K. S. Balkcom, ${ }^{3}$ C. W. Wood, ${ }^{1}$ and J. F. Adams ${ }^{1,2}$ \\ ${ }^{1}$ Department of Agronomy and Soils, Auburn University, Auburn, Alabama, USA \\ ${ }^{2}$ Deceased \\ ${ }^{3}$ USDA-ARS, National Soil Dynamics Laboratory, Auburn, Alabama, USA
}

\begin{abstract}
Leguminous crops, particularly winter annuals, have been utilized in conservation systems to partially meet nitrogen $(\mathrm{N})$ requirements of succeeding summer cash crops. Previous research also highlights the benefits of utilizing summer annual legumes in rotation with non-leguminous crops. This study assessed the $\mathrm{N}$ contribution of peanut (Arachis hypogaea L.) residues to a subsequent cotton (Gossypium hirsitum L.) crop in a conservation system on a Dothan sandy loam (fine-loamy, kaolinitic, thermic Plinthic Kandiudults) at Headland, AL during the 2003-2005 growing seasons. Treatments were arranged in a split plot design, with main plots of peanut residue retained or removed from the soil surface, and subplots as $\mathrm{N}$ application rates $\left(0,34,67\right.$, and $\left.101 \mathrm{~kg} \mathrm{ha}^{-1}\right)$ applied in fall and spring. Peanut residue did not influence seed cotton yields, leaf $\mathrm{N}$ concentrations, or plant $\mathrm{N}$ uptake for either growth stage or year of the experiment. There was a trend for peanut residue to increase whole plant biomass measured at the first square in two of three years. Seed cotton yields and plant parameters measured at the first square and mid-bloom responded favorably to spring $\mathrm{N}$ applications, but the recommended $101 \mathrm{~kg} \mathrm{~N}^{-1}$ did not maximize yields. The results from this study indicate that peanut residue does not contribute significant amounts of $\mathrm{N}$ to a succeeding cotton crop, however, retaining residue on the soil surface provides other benefits to soils in the southeastern U.S.
\end{abstract}

Keywords: first square, leaf $\mathrm{N}$ concentration, mid-bloom, nitrogen uptake, seed cotton yields, whole plant biomass

Received 6 April 2006; accepted 25 September 2006.

Address correspondence to K.S. Balkcom, USDA-ARS, National Soil Dynamics Laboratory, 411 S. Donahue Dr., Auburn, AL 36832, USA. Email: kbalkcom@ars. usda.gov 


\section{INTRODUCTION}

Tillage systems that maintain crop residues on the soil surface can reduce erosion, use less on-farm energy, and result in more available soil water (Unger and McCalla, 1980). Legume crop residues have been extensively evaluated in the southeastern U.S. primarily in conservation tillage systems to improve crop production and enhance soil physical characteristics (Mitchell and Teel, 1977; Touchton et al., 1984; Hargrove, 1986; Oyer and Touchton, 1990). Typically, legumes are planted after harvest in the fall and terminated in the spring. A summer crop is planted into the residue. A major benefit usually associated with legumes is the potential reduction in $\mathrm{N}$ fertilizer expenses for subsequent cash crops.

In the Southeast, winter annual legumes, such as crimson clover (Trifolium incarnatum $\mathrm{L}$.) and hairy vetch (Vicia villosa Roth.), are utilized as nitrogen (N) sources for summer crops (Touchton et al., 1984; Brown et al., 1985; Reeves, 1994). Balkcom and Reeves (2005) also showed how sunn hemp, a summer legume, could be utilized to decrease corn $\mathrm{N}$ requirements. In addition, summer cash legumes have also been examined as a $\mathrm{N}$ source for subsequent crops. Researchers in the U.S. Corn Belt have found that alfalfa (Medicago sativa L.) and soybean (Glycine max L.), can decrease the fertilizer $\mathrm{N}$ requirements of a succeeding corn (Zea mays L.) crop (Bruulsema and Christie, 1987; Bundy et al., 1993; Morris et al., 1993). More recent research in the southern U.S. involving summer cash legumes, e.g., soybean or peanut grown in rotation with a cotton crop, has primarily focused on nematode management. Researchers have focused on the potential nematode suppressive effect of a summer cash legume (Westphal and Scott, 2005) and not the $\mathrm{N}$ requirements of cotton following a particular summer cash legume.

A peanut-cotton rotation is popular among growers in the Southeast (Johnson et al., 2001). Current cotton recommendations indicate that the residue of a high-yielding soybean or peanut crop may contribute up to $34 \mathrm{~kg} \mathrm{~N} \mathrm{ha}^{-1}$ to the subsequent cotton crop (Adams et al., 1994). Mitchell (2000) reported that $\mathrm{N}$ response of cotton following summer legume residues may be erratic in long-term rotation trials conducted throughout Alabama. In South Carolina, Hunt et al. (1998) reported a low potential of $\mathrm{N}$ contribution to the soil system, which was consistent with their observation of no cotton yield response following peanut. An incubation of two soils with and without two types of peanut residue also indicated no significant amounts of $\mathrm{N}$ were mineralized under laboratory conditions (Balkcom et al., 2004). In contrast, other incubation studies have indicated peanut residues mineralized $\mathrm{N}$ and increased mineralization of indigenous and fertilizerderived soil N (Smith and Sharpley, 1990; Constantinides and Fownes, 1994). Therefore, our objective was to compare the $\mathrm{N}$ response of cotton in a conservation tillage system following the removal and retention of peanut residue. 


\section{MATERIALS AND METHODS}

This experiment was established in October 2002 at the Wiregrass Research and Extension Center in Headland, AL on a Dothan sandy loam. The experimental area was moved to a different location each year to utilize peanut residue from the previous peanut crop, but remained on a Dothan sandy loam. Treatments were arranged in a split-plot design with four replications. Main plots consisted of the retention or removal of peanut residue from the soil surface following mechanical harvest of peanut pods. Peanut residue was removed by mechanically raking into windrows and baling the peanut residue. Average peanut biomass was estimated by weighing the baled residue. A subsample of the residue was dried at $55^{\circ} \mathrm{C}$ for $72 \mathrm{~h}$ and ground to pass a 2-mm screen with a Wiley mill (Thomas Scientific, Swedesboro, NJ) then further ground to pass a 1-mm screen with a Cyclone grinder (Thomas Scientific, Swedesboro, NJ). The peanut residue was analyzed for total $\mathrm{N}$ by dry combustion on a LECO CN-2000 analyzer (Leco Corp., St. Joseph, MI).

A rye cover crop was drilled at $101 \mathrm{~kg} \mathrm{ha}^{-1}$ across the experimental area on November 20, 2002, October 30, 2003, and November 15, 2004. Subplot treatments were $\mathrm{N}$ rates $\left(0,34,67\right.$, and $\left.101 \mathrm{~kg} \mathrm{~N} \mathrm{ha}^{-1}\right)$ hand-applied in the fall, as ammonium nitrate $\left(\mathrm{NH}_{4} \mathrm{NO}_{3}\right)$, to the cover crop and again in the spring after cotton planting. Nitrogen was applied to the rye cover crop on November 21 , 2002, November 14, 2003, and December 3, 2004. Plot dimensions were $7.3 \mathrm{~m}$ wide (8-36 in. rows) and $12.2 \mathrm{~m}$ long. Fifteen soil cores $(2.5 \mathrm{~cm}$ diam.) were randomly collected from the surface $15 \mathrm{~cm}$ of each plot, prior to $\mathrm{N}$ application in the spring. Soils were dried at $105^{\circ} \mathrm{C}$ for $24 \mathrm{~h}$ in a forced air oven and sieved with a $2 \mathrm{~mm}$ screen. Initial ammonium $\left(\mathrm{NH}_{4}\right)-\mathrm{N}$ and nitrate $\left(\mathrm{NO}_{3}\right)-\mathrm{N}$ concentrations were determined colorimetrically with a microplate reader (Sims et al., 1995) (Table 1).

DPL 555 BG/RR (Delta Pine and Land Co., Scott, MS) was planted on May 5, 2003 and May 19, 2004 and DPL 444 BG/RR (Delta Pine and Land Co., Scott, MS) was planted on May 11, 2005 at 11.5 seeds $\mathrm{m}^{-1}$. Cotton planted in 2004 was damaged by Rhizoctonia and re-planted with a shorter season cultivar (DPL 444 BG/RR) on June 21, 2004. In 2003, N was hand-applied to selected plots on 15 May 2003 in one application. In 2004 and 2005, N applications were split-applied with $34 \mathrm{~kg} \mathrm{~N} \mathrm{ha}^{-1}$ applied to all fertilized plots on July 9, 2004 and June 13, 2005. The remaining 34 or $67 \mathrm{~kg} \mathrm{~N} \mathrm{ha}^{-1}$ was applied on July 23, 2004 and June 23, 2005. Fifty uppermost fully expanded leaves were collected from each plot two times during the growing season (1st square and mid-bloom). Sample times for 1st square corresponded to June 26, 2003, August 6, 2004, and July 1, 2005, while mid-bloom corresponded to July 22, 2003, August 28, 2004, and July 18, 2005. Petioles were separated from leaves, and the leaves were dried, ground, and analyzed for total $\mathrm{N}$ using dry combustion procedures described above. At each sample time, all above ground plant parts (squares, bolls, leaves, stems) were removed from a $1 \mathrm{~m}$ 
Table 1

Background soil $\mathrm{NH}_{4}-\mathrm{N}$ and $\mathrm{NO}_{3}-\mathrm{N}$ (composite of 15 individual cores) concentrations, prior to cotton establishment in the top $15 \mathrm{~cm}$, at the Wiregrass Research and Extension Center in Headland, AL

\begin{tabular}{|c|c|c|c|c|c|c|}
\hline \multirow[b]{2}{*}{ Treatment } & \multicolumn{2}{|c|}{2003} & \multicolumn{2}{|c|}{2004} & \multicolumn{2}{|c|}{2005} \\
\hline & $\mathrm{NH}_{4}-\mathrm{N}$ & $\mathrm{NO}_{3}-\mathrm{N}$ & $\mathrm{NH}_{4}-\mathrm{N}$ & $\mathrm{NO}_{3}-\mathrm{N}$ & $\mathrm{NH}_{4}-\mathrm{N}$ & $\mathrm{NO}_{3}-\mathrm{N}$ \\
\hline & \multicolumn{6}{|c|}{$\mathrm{mg} \mathrm{kg}^{-1}$} \\
\hline \multicolumn{7}{|l|}{ Peanut residue } \\
\hline Retained & 2.5 & 1.1 & 4.8 & 10.0 & 8.5 & 3.0 \\
\hline Removed & 2.4 & 1.1 & 5.0 & 10.5 & 8.3 & 4.5 \\
\hline \multicolumn{7}{|l|}{$\mathrm{N}$ rate, $\mathrm{kg} \mathrm{ha}^{-1} \dagger$} \\
\hline 0 & 2.5 & 0.6 & 5.0 & 9.9 & 9.0 & 4.2 \\
\hline 34 & 2.6 & 1.0 & 4.9 & 10.3 & 8.3 & 3.3 \\
\hline 67 & 2.5 & 1.3 & 4.9 & 10.8 & 7.7 & 4.1 \\
\hline \multirow[t]{2}{*}{101} & 2.4 & 1.6 & 4.8 & 10.0 & 8.4 & 3.5 \\
\hline & \multicolumn{6}{|c|}{ Analysis of variance $(\mathrm{P}>\mathrm{F})$} \\
\hline Peanut residue & 0.6623 & 0.9976 & 0.7931 & 0.7323 & 0.7956 & 0.4404 \\
\hline $\mathrm{N}$ rate & 0.8150 & 0.0769 & 0.9770 & 0.8207 & 0.3836 & 0.8048 \\
\hline linear & & 0.0116 & & & & \\
\hline quadratic & & 0.7195 & & & & \\
\hline Interaction & 0.5733 & 0.8362 & 0.6398 & 0.3528 & 0.9316 & 0.6246 \\
\hline
\end{tabular}

${ }^{\dagger}$ Fall $\mathrm{N}$ rate.

strip randomly selected from non-harvest rows within each plot to determine whole plant dry matter production, $\mathrm{N}$ concentration, and $\mathrm{N}$ uptake. Seed cotton yields were determined by mechanically harvesting with a spindle-picker and weighing the lint and seed from the two center rows of each plot.

All response variables were analyzed using the MIXED procedure (Littell et al., 1996) and the LSMEANS PDIFF option to distinguish between treatment means (release 9.1; SAS Institute Inc.; Cary, NC). Data were analyzed with year as a fixed effect in the model, and there were significant year X treatment interactions for all response variables. Therefore, data were analyzed within each year, with data and discussion presented by year. Peanut residue and $\mathrm{N}$ rate were also considered as fixed effects, while rep and rep X peanut residue were considered random. Single degree-of-freedom contrasts were used to evaluate linear and quadratic effects of $\mathrm{N}$ rates on each response variable. If a single degree-of-freedom contrast indicated a significant linear or quadratic response, the specified regression model was fit with the PROC REG procedure (SAS Institute, 2002). Treatment differences were considered significant if $\mathrm{P} \leq 0.10$. 


\section{RESULTS AND DISCUSSION}

Soil samples were collected from each plot in the spring to determine inorganic $\mathrm{N}$ concentrations at planting and determine to what extent peanut residue or fall applied $\mathrm{N}$ rates affected the residual $\mathrm{N}$ status, prior to cotton establishment. The retention or removal of peanut residue had no effect on residual mineral $\mathrm{N}$ status in the top $15 \mathrm{~cm}$ (Table 1). Fluctuations in concentrations and different proportions of $\mathrm{NH}_{4}-\mathrm{N}$ or $\mathrm{NO}_{3}-\mathrm{N}$ were observed among years, but concentrations remained low. Fall $\mathrm{N}$ applied to the rye cover crop did not increase mineral $\mathrm{N}$ in the spring or interact with peanut residue, except during the 2003 growing season (Table 1). A linear relationship was observed between fall applied $\mathrm{N}$ rates and soil $\mathrm{NO}_{3}-\mathrm{N}$ concentrations, but the observed soil $\mathrm{NO}_{3}-\mathrm{N}$ concentrations were $<2 \mathrm{mg} \mathrm{kg}^{-1}$. Spring soil $\mathrm{NO}_{3}-\mathrm{N}$ concentrations are typically not collected in the humid Southeast because of limited success of the test (Lutrick et al., 1986). The sandier soils combined with high precipitation during the winter and early spring could explain why soil testing for inorganic $\mathrm{N}$ is not successful in the region. However, the low concentrations observed indicate that residual $\mathrm{N}$ fertility likely did not influence subsequent measured cotton variables.

\section{PEANUT RESIDUE}

Seed cotton yields and leaf $\mathrm{N}$ concentrations, whole plant biomass, and $\mathrm{N}$ uptake measured at two growth stages did not respond to the retention of peanut residue on the soil surface (Table 2). However, in two out of three years, there was a trend for greater whole plant biomass weights at 1st square when peanut residue was retained on the soil surface. The absence of any consistent response among these measured variables indicates that expecting an $\mathrm{N}$ credit from peanut residue to a subsequent cotton crop may be unrealistic and peanut residue should not be promoted as having the capability to supply up to $34 \mathrm{~kg} \mathrm{~N} \mathrm{ha}^{-1}$.

Peanut residue biomass averaged $3250 \mathrm{~kg} \mathrm{ha}^{-1}$ with an $\mathrm{N}$ concentration of $14 \mathrm{~g} \mathrm{~kg}^{-1}$ across all three years of the experiment. This $\mathrm{N}$ concentration was comparable to that reported by Balkcom et al. (2004) for post-harvest peanut residue. Based on the residue production and $\mathrm{N}$ concentration, peanut residue had a total $\mathrm{N}$ accumulation of nearly $46 \mathrm{~kg} \mathrm{ha}^{-1}$. However, not all the $\mathrm{N}$ will be immediately available. Decomposition of the residue by soil microbes is required and what portion of the $\mathrm{N}$ the microbes do not use during the decomposition process will be potentially available for plant uptake and/or $\mathrm{N}$ loss pathways (i.e., leaching). This amount of $\mathrm{N}$ accumulation and subsequent uncertainty associated with the release of the accumulated $\mathrm{N}$ could explain the recommendation by Adams et al. (1994) of the potential contribution of up to $34 \mathrm{~kg} \mathrm{~N} \mathrm{ha}^{-1}$ following a good peanut crop. Mitchell (2000) observed on a Benndale fine sandy loam (coarse-loamy, siliceous, semiactive, thermic 


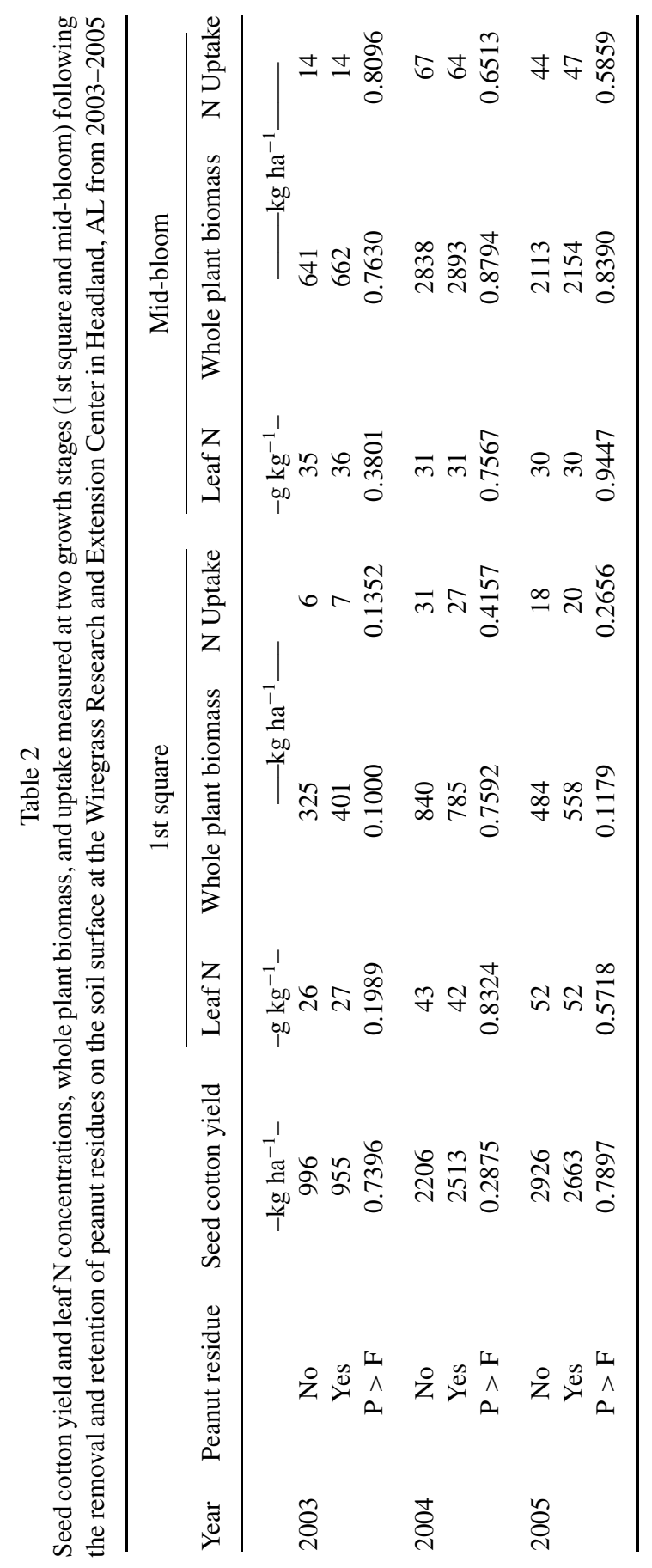




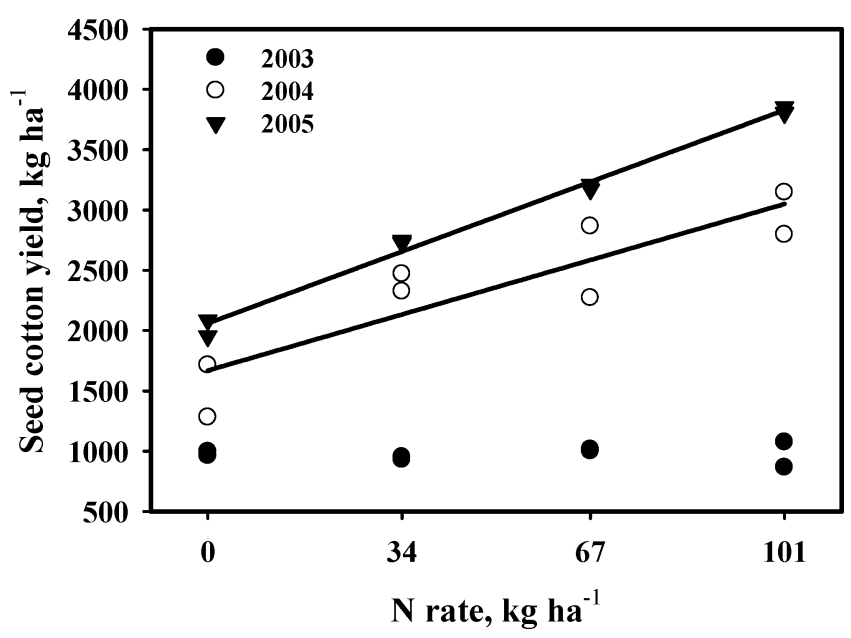

Figure 1. Seed cotton yield measured following the removal and retention of peanut residues on the soil surface and the application of spring $\mathrm{N}$ fertilizer at the Wiregrass Research and Extension Center in Headland, AL from 2003-2005.

Typic Paleudult) that cotton yields were only maximized with the standard $\mathrm{N}$ recommendation, although the cotton crop followed a legume.

\section{APPLIED NITROGEN}

Seed cotton yields did respond to applied N during the 2004 and 2005 growing seasons, but the linear response to applied $\mathrm{N}$ indicated that the $101 \mathrm{~kg} \mathrm{~N}^{-1}$ rate did not maximize yields (Figure 1; Table 3 ). Seed cotton yields measured in 2005 were slightly higher and were less variable than measured yields for the 2004 growing season. The lower observed yields may be partially attributed to delayed planting in 2004 and possibly better growing conditions in 2005 . Significant rainfall measured during the critical fruiting months of June, July, and August combined with higher heat units in 2005 could explain the observed yield differences between years (Figure 1). No response to applied N was observed during the 2003 growing season, although heat units and rainfall were comparable to the following growing seasons (Table 4). This may be explained by the single application time of corresponding $\mathrm{N}$ treatments soon after cotton planting and the $65 \mathrm{~mm}$ of rainfall that fell over a $7 \mathrm{~d}$ period immediately following $\mathrm{N}$ applications. It is presumed that the $\mathrm{N}$ leached below the root zone of the sandy soil and the cotton roots never had access to this $\mathrm{N}$.

The lack of response to applied $\mathrm{N}$ during the 2003 growing season is also illustrated by measured leaf $\mathrm{N}$ concentrations, whole plant biomass, and plant $\mathrm{N}$ uptake at 1 st square and mid-bloom (Figure 2). Measured variables across both 


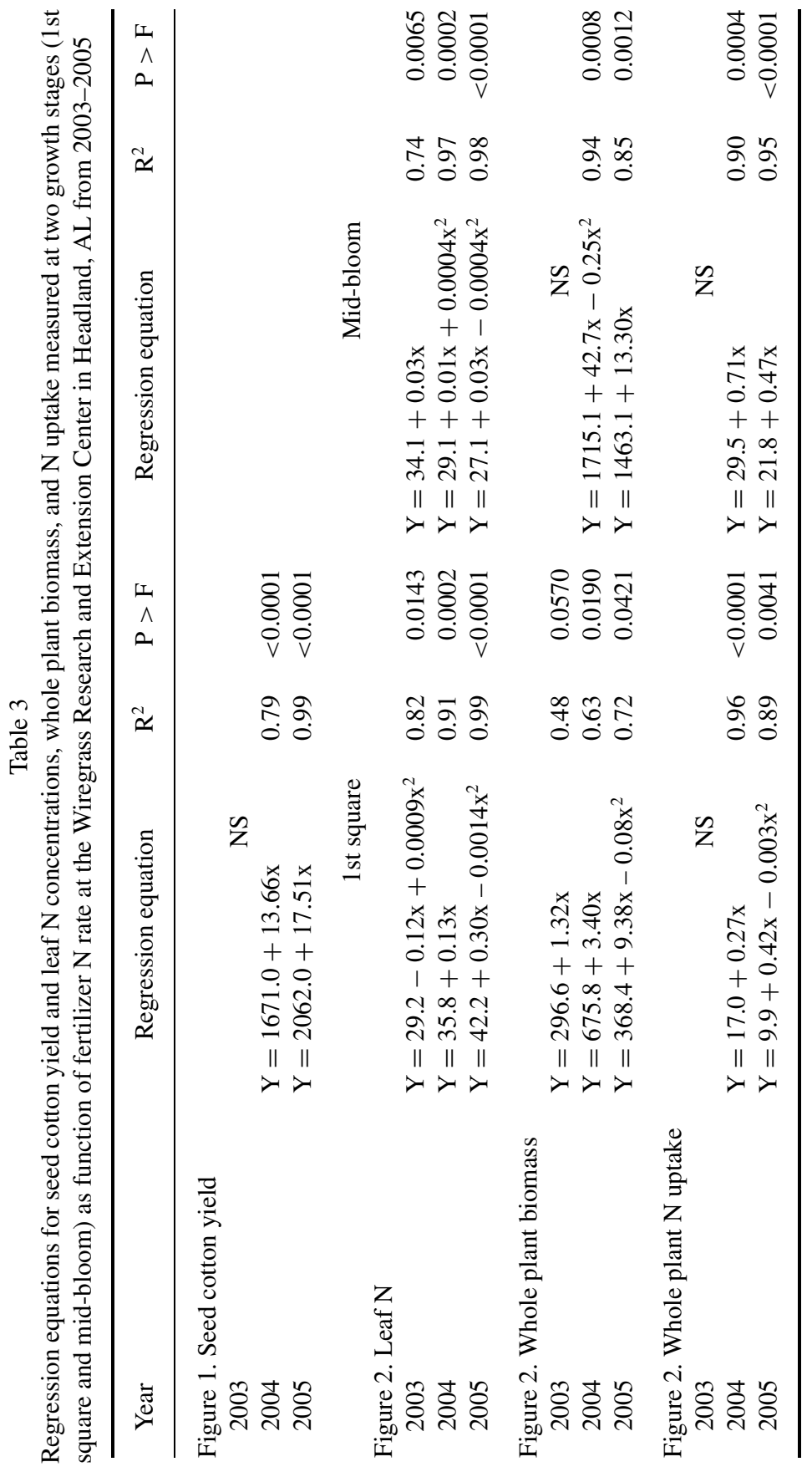


Table 4

Measured rainfall and heat units observed during the 2003, 2004, and 2005 growing season at the Wiregrass Research and Extension Center in Headland, AL

\begin{tabular}{|c|c|c|c|c|c|c|}
\hline \multirow[b]{2}{*}{ Month } & \multicolumn{2}{|c|}{2003} & \multicolumn{2}{|c|}{2004} & \multicolumn{2}{|c|}{2005} \\
\hline & Heat units ${ }^{\dagger}$ & Rainfall & Heat units & Rainfall & Heat units & Rainfall \\
\hline May & 442 & $\begin{array}{c}-\mathrm{mm}- \\
77\end{array}$ & & $-\mathrm{mm}-$ & 333 & $\begin{array}{c}-\mathrm{mm}- \\
60\end{array}$ \\
\hline June & 569 & 197 & 194 & 223 & 577 & 247 \\
\hline July & 620 & 157 & 665 & 105 & 686 & 136 \\
\hline August & 635 & 147 & 629 & 46 & 649 & 201 \\
\hline September & 476 & 110 & 491 & 161 & 579 & 44 \\
\hline October & 71 & 42 & 354 & 70 & 99 & 2 \\
\hline November & & & 116 & 121 & & \\
\hline December & & & 4 & 66 & & \\
\hline Total & 2813 & 730 & 2453 & 792 & 2923 & 690 \\
\hline
\end{tabular}

${ }^{\dagger}$ Heat units were calculated with the following formula $\left((\operatorname{Tmax}+\operatorname{Tmin} / 2)-15.5^{\circ} \mathrm{C}\right)$. $\mathrm{Tmax}=$ daily maximum temperature and $\mathrm{Tmin}=$ daily minimum temperature. $\mathrm{Calcu}-$ lations began on the day of planting and ended on the day of harvest.

growth stages were consistently lower with or without any response to applied $\mathrm{N}$, except for leaf $\mathrm{N}$ concentrations at mid-bloom compared to the other two growing seasons. One explanation for increased leaf $\mathrm{N}$ concentration at midbloom for the deficient 2003 growing season is that the cotton roots were able to grow down deep enough to intercept some of the applied N. Presumably, the plants were very small at this point and reproductive parts were few or non-existent, which enabled the leaf $\mathrm{N}$ concentration to spike. However, the plants could not access enough $\mathrm{N}$ to overcome the previous deficiency. Another explanation could be that plants were sampled slightly earlier than mid-bloom, which could result in slightly higher leaf $\mathrm{N}$ concentrations compared to the other growing seasons for reasons described below.

Differences between leaf $\mathrm{N}$ concentrations, whole plant biomass, and $\mathrm{N}$ uptake are apparent between growth stages (Figure 2). At 1st square, leaf $\mathrm{N}$ concentrations were highest and increased as $\mathrm{N}$ rates increased with the exception of the clearly deficient 2003 growing season. The linear and quadratic increase of leaf $\mathrm{N}$ concentration as $\mathrm{N}$ rate increased (Table 3) is consistent with the plant partitioning $\mathrm{N}$ to the younger leaves (upper main stem leaves) and reproductive parts when $\mathrm{N}$ is not limited (Tewolde et al., 2005). As dry matter accumulation increased (1st square to mid-bloom), $\mathrm{N}$ is partitioned to reproductive structures, which would decrease leaf $\mathrm{N}$ concentrations in the younger leaves (Bell et al., 2003; Tewolde et al., 2005). However, the reported critical leaf $\mathrm{N}$ concentration measured at mid-bloom for the Southeast Cotton 

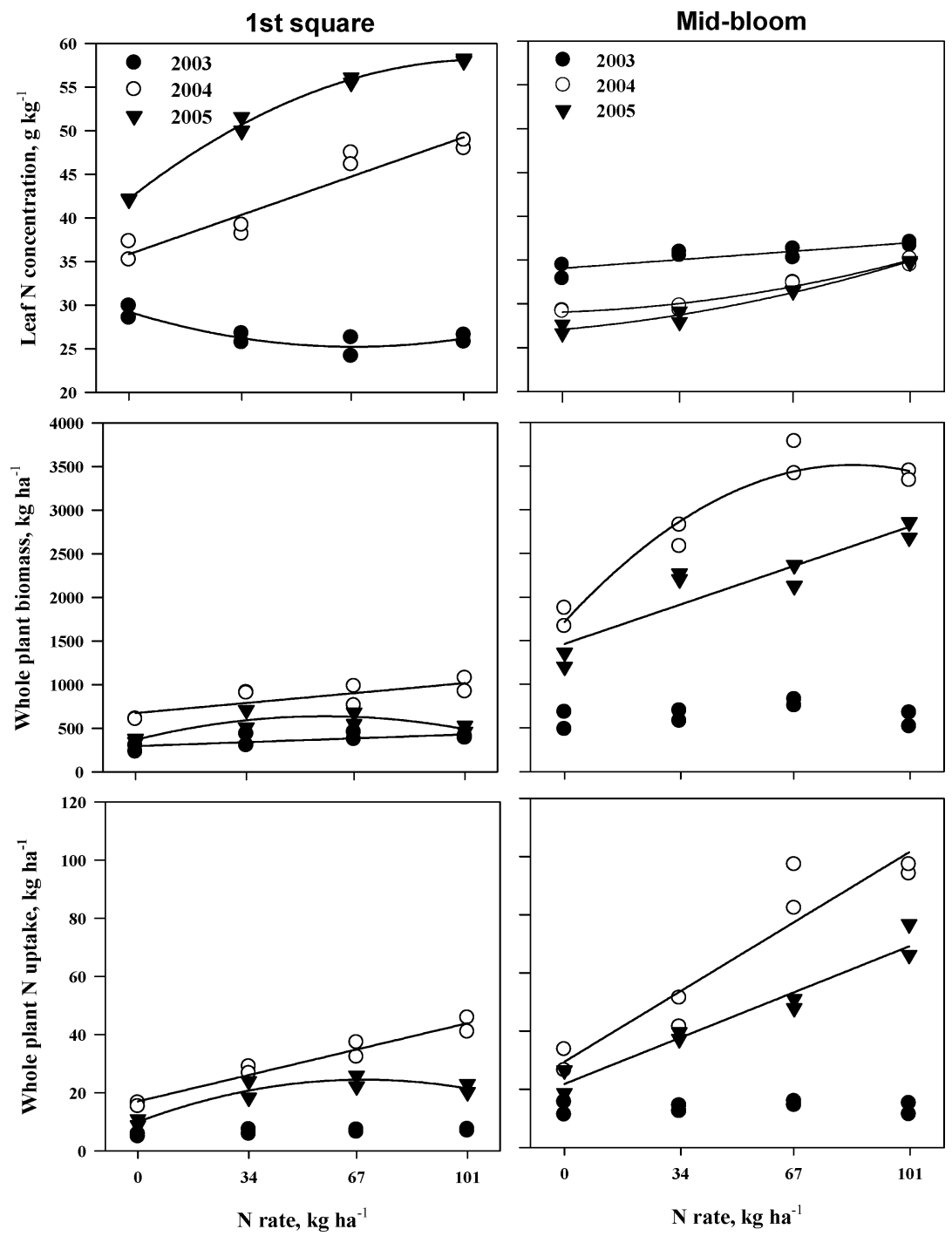

Figure 2. Leaf $\mathrm{N}$ concentrations, whole plant biomass, and uptake measured at two growth stages (1st square and mid-bloom) following the removal and retention of peanut residues on the soil surface and the application of spring $\mathrm{N}$ fertilizer at the Wiregrass Research and Extension Center in Headland, AL from 2003-2005.

Belt is $41 \mathrm{~g} \mathrm{~kg}^{-1}$ (Bell et al., 2003). No leaf $\mathrm{N}$ concentrations measured at mid-bloom were above this reported critical level for any growing season. This may explain why seed cotton yields were not maximized at $101 \mathrm{~kg} \mathrm{~N}^{-1}$ (Figure 1). 


\section{CONCLUSIONS}

Peanut residue did not contribute significant amounts of $\mathrm{N}$ to the subsequent cotton crop based on seed cotton yield response and various tissue samples collected at 1 st square and mid-bloom over a 3-yr period. As expected, cotton did respond favorably to $\mathrm{N}$ applications, but the recommended $101 \mathrm{~kg} \mathrm{~N} \mathrm{ha}^{-1}$ did not maximize yields. These findings indicate that soil test recommendations may need to be altered so as not to suggest that $\mathrm{N}$ rates following a peanut crop can be reduced up to $34 \mathrm{~kg} \mathrm{~N} \mathrm{ha}^{-1}$ in a conservation system. Although recommendations state that $\mathrm{N}$ rates may be potentially reduced, the probability of this occurring is much less than the probability of no response to peanut residue. Since peanut production in the Southeast is generally on highly weathered Ultisols, retention of peanut residue in the field could increase soil organic matter contents, which will improve soil physical and chemical properties.

\section{ACKNOWLEDGMENTS}

The authors would like to acknowledge the technical support provided by Jeffrey Walker, Agricultural Science Technician, USDA-ARS and Brenda Wood, Research Associate, Department of Agronomy and Soils, Auburn University.

\section{REFERENCES}

Adams, J. F., C. C. Mitchell, and H. H. Bryant. 1994. Soil test fertilizer recommendations for Alabama crops. Alabama Agriculture Experiment Station, Agronomy and Soils Department Series. No. 178.

Balkcom, K. S., and D. W. Reeves. 2005. Sunn-hemp utilized as a legume cover crop for corn production. Agronomy Journal 97: 26-31.

Balkcom, K. S., C. W. Wood, J. F. Adams, and B. H. Wood. 2004. Composition and decomposition of peanut residues in Georgia. Peanut Science 31: 6-11.

Bell, P. F., D. J. Boquet, E. Millhollon, S. Moore, W. Ebelhar, C. C. Mitchell, J. Varco, E. R. Funderburg, C. Kennedy, G. A. Breitenbeck, C. Craig, M. Holman, W. Baker, and J. S. McConnell. 2003. Relationships between leaf-blade nitrogen and relative seedcotton yields. Crop Science 43: 13671374.

Brown, S. M., T. Whitwell, J. T. Touchton, and C. H. Burmester. 1985. Conservation tillage systems for cotton production. Soil Science Society of America Journal 49: 1256-1260.

Bruulsema, T. W., and B. R. Christie. 1987. Nitrogen contribution to succeeding corn from alfalfa and red clover. Agronomy Journal 79: 96-100. 
Bundy, L. G., T. W. Andraski, and R. P. Wolkowski. 1993. Nitrogen credits in soybean-corn crop sequences on three soils. Agronomy Journal 85: 10611067.

Constantinides, M., and J. H. Fownes. 1994. Nitrogen mineralization from leaves and litter of tropical plants: relationship to nitrogen, lignin and soluble polyphenol concentrations. Soil Biology \& Biochemistry 26: 49-55.

Hargrove, W. L. 1986. Winter legumes as a nitrogen source for no-till grain sorghum. Agronomy Journal 78: 70-74.

Hunt, P. G., P. J. Bauer, C. R. Camp, and T. A. Matheny. 1998. Nitrogen accumulation in cotton grown continuously or in rotation with peanut using subsurface microirrigation and GOSSYM/COMAX management. Crop Science 38: $410-415$.

Johnson, W. C., III, T. B. Brenneman, S. H. Baker, A. W. Johnson, D. R. Sumner, and B. G. Mullinix, Jr. 2001. Tillage and pest management considerations in a peanut-cotton rotation in the southeastern Coastal Plain. Agronomy Journal 93: 570-576.

Littell, R. C., G. A. Milliken, W. W. Stroup, and R. D. Wolfinger. 1996. SAS system for mixed models. Cary, North Carolina: SAS Institute.

Lutrick, M. C., H. A. Peacock, and J. A. Cornell. 1986. Nitrate monitoring for cotton lint production on a Typic Paleudult. Agronomy Journal 78: 1041-1046.

Mitchell C. C. 2000. Nitrogen rates for cotton in Alabama's long-term experiments. In Proceedings of the Beltwide Cotton Conferences, eds. C. P. Duggar and D. A. Richter, 1388-1392. Memphis, Tennessee: National Cotton Council.

Mitchell, W. H., and M. R. Teel. 1977. Winter-annual cover crops for no-tillage corn production. Agronomy Journal 69: 569-573.

Morris, T. F., A. M. Blackmer, and N. M. El-Hout. 1993. Optimal rates of nitrogen fertilization for first-year corn after alfalfa. Journal of Production Agriculture 6: 344-349.

Oyer, L. J., and J. T. Touchton. 1990. Utilizing legume cropping systems to reduce nitrogen fertilizer requirements. Agronomy Journal 82: 11231127.

Reeves, D. W. 1994. Cover crop and rotations, In Crops Residue Management, eds. J. L. Hatfield and B. A. Stewart, 125-172. Boca Raton: Lewis Publishers.

SAS Institute. 2002. The SAS System for Windows. Release 9.1. SAS Institute, Cary.

Sims, G. K., T. R. Ellsworth, and R. L. Mulvaney. 1995. Microscale determination of inorganic nitrogen in water and soil extracts. Communications in Soil Science and Plant Analysis 26: 303-316.

Smith, S. J., and A. N. Sharpley. 1990. Soil nitrogen mineralization in the presence of surface and incorporated crop residues. Agronomy Journal 82: $112-116$. 
Tewolde, H., K. R. Sistani, and D. E. Rowe. 2005. Broiler litter as a sole nutrient source for cotton: Nitrogen, phosphorus, potassium, calcium, and magnesium concentrations in plant parts. Journal of Plant Nutrition 28: 605619.

Touchton, J. T., D. H. Rickerl, R. H. Walker, and C. E. Snipes. 1984. Winter legumes as a nitrogen source for no-tillage cotton. Soil \& Tillage Research 4: 391-401.

Unger, P. W., and T. M. McCalla. 1980. Conservation tillage systems. Advances in Agronomy 33: 1-58.

Westphal, A., and A. W. Scott, Jr. 2005. Implementation of soybean in cotton cropping sequences for management of reniform nematode in South Texas. Crop Science 45: 233-239. 